\title{
Demographic variables affecting participation in mammography screening: a cross-sectional study
}

\author{
Hatice Özkoç ${ }^{1}$ \\ 1 Mugla Sitki Kocman University, Faculty of Economics and Administrative Sciences, Department of Business, Turkey \\ e-mail: haticeozkoc@gmail.com
}

\begin{abstract}
Breast cancer is one of the most common cancers among women. There are three commonly used diagnostic methods in this particular cancer type, for which the survival rate can be quite high with early diagnosis. Compared to breast self-examination and clinical examination, mammography stands out as a more accurate diagnostic method. Although there are health policies regarding mammography screening in many countries, mammography screening behavior has not reached to the desired level worldwide. In this study, we aim to reveal the demographic factors affecting the frequency of women getting mammograms in Turkey. The frequency of mammography screening was estimated with a generalized logit model using the microdata of TURKSTAT "Turkey Health Survey". As a result, we found that the mammography screening differentiated across different age and income groups. The disease status was reported to increase the frequency of mammography screening. However, marital status and employment status did not have any significant effect.
\end{abstract}

Keywords: Breast Cancer, Mammography, Income Levels, Ordered Categorical Dependent Variable, Generalized Ordered Logit Model

JEL Codes: C02, 112

Citation: OZKOC, H. (2021). Demographic Variables Affecting Participation in Mammography Screening: A Cross-Sectional Study. Journal of Applied Microeconometrics (JAME). 1(1), 18-26, DOI:10.53753/jame.1.1.02 


\section{INTRODUCTION}

Breast cancer, the most frequently diagnosis among women, is also a leading cause of cancer deaths (Bhandari et al. 2021). According to the GLOBACAN (2020) report published by The International Agency for Research on Cancer, breast cancer is one of the most common (24.5\%), rapidly spreading and therefore important cancer types among women. In 2020, the female population in the world was 3,864,824,712, and in the same year, 9,227,484 women were newly diagnosed with cancer. 2,261,419 of them were reported to be diagnosed with breast cancer. Looking at women's deaths due to cancer worldwide in the same year, it is observed that deaths due to breast cancer ranked fourth $(684,996)$ (GLOBACAN 2020). Bhandari et al. (2021) stated that breast cancer deaths differ from each other in low- and high-income countries. In the same study, it was stated that the death rate is three times higher in low-income countries. Figure 2 shows the percentages of the 10 most common cancer types among women in Turkey. As seen in the figure, breast cancer ranks first among other cancers with $24.8 \%$.

Figure 1. The number of new cancer cases in women in 2020

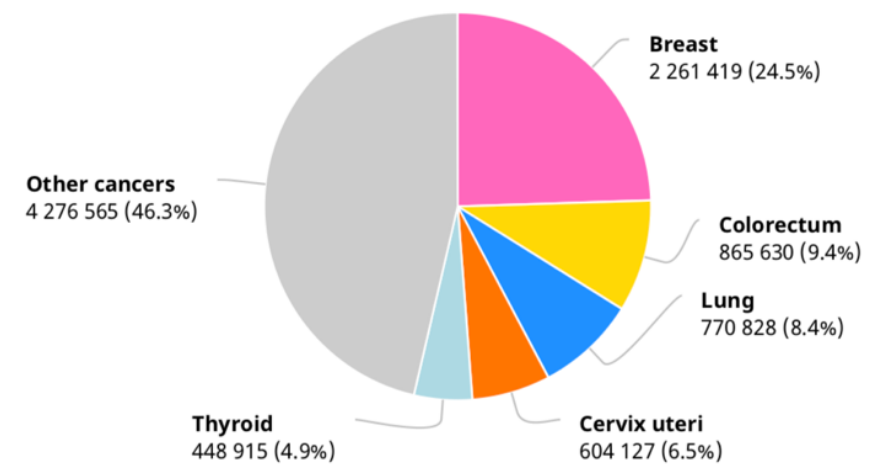

Source:The Global Cancer Observatory

While deaths associated with breast cancer rank first among the leading causes of death in females in underdeveloped countries, it comes after lung cancer in developed countries (Karaca et al. 2019). It was estimated that approximately $15 \%$ of cancer deaths among women were due to breast cancer (Torre et al. 2015). While $2 \%$ of total deaths in the EU in 2017 were due to breast cancer, this rate was 1\% in Turkey during the same period (Health Statistics Yearbook 2019). Among the 20 most common causes of death in women in Turkey, breast cancer ranks the 8th with 2.1\% (Akova, Hasdemir and Türkoğlu 2019: 90). While the incidence of breast cancer per 100,000 is 45.6 in Turkey, this value is 79 in the EU (Health Statistics Yearbook 2019).

Figure 2. Prevalence of the Most Common 10 Cancer Types Among Females in the Total Prevalence, Turkey, (\%), 2016

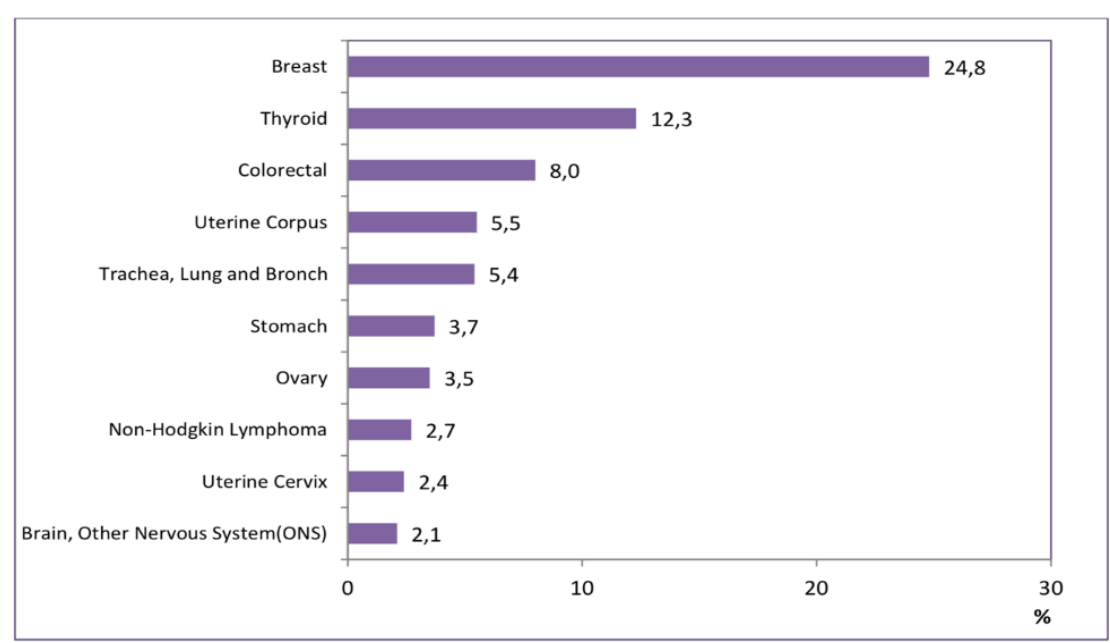

Source: Ministry of Health 
The GLOBACAN (2020) report states that 2.6 million women worldwide will have breast cancer in 2030 and 817 thousand women will die from breast cancer. Cancer screening is one of the most effective methods in the fight against cancer in order to create awareness in society regarding cancer. Screening methods with proven efficacy are used in order to detect breast cancer at an early stage. Breast cancer is a progressive disease and is more likely to be cured when diagnosed early. Hereby, life expectancy is high. It is stated that the 5-year survival rate in patients diagnosed with breast cancer with early diagnosis and treatment methods in developed countries is approximately 90-95\% (Akova, Hasdemir and Türkoğlu 2019: 90; Aslaner 2019: 8).

There are three methods generally used for early diagnosis of breast cancer. These are Mammography, Clinical and breast self-examination (Bhandari et al. 2021). Compared to breast self-examination and physician examination, mammographic screening can help detect breast cancer earlier (Karaca et al. 2019) and is recommended as a standard screening test worldwide (Bhandari et al. 2021).

Turkey is one of those countries implementing a national breast cancer screening program (National Cancer Institute 2015). In Turkey, mammography is one of the most preferred screening methods for breast cancer screening due to its applicability and easy accessibility for women. According to the standards set by the Cancer Department of the General Directorate of Turkish Public Health, women aged 40-69 get mammograms every two years. In addition, clinical breast examination is recommended for women participating in screening to increase the effectiveness of mammography (Aşkin et al. 2019: 26).

In this study, the mammographic screening will be discussed and it will be examined whether there is a difference in mammography behaviors in the context of demographic characteristics. This study aims to examine the relationship between demographic characteristics and the frequency of mammography screening using the Generalized Ordered Logit model. In the following chapters, the studies in the literature that examine mammography behavior in the context of demographic characteristics will be included. Then, the qualitative preference model results will be included, based on a micro data set obtained at the national level.

\section{LITERATURE}

The common purpose of the studies in the literature regarding the acceptance and application of breast cancer screening methods is to increase the acceptance of these methods by women and thus to increase the early diagnosis rates.

In different studies, the rate of women getting mammograms varies between 3.4\% and 85\% (Bhandari et al. 2021; Ghanbari et al. 2020; Aşkın et al. 2019). This arising wide ranged ratio brings these questions along: "What is the reason for such a high difference?" and "How can this ratio be increased?". In one of the studies conducted with the aim of finding answers to these questions, Aşkın et al. (2019) examined the relationship between mammography screening and sociodemographic variables using logistic regression. Their results suggested that age and education status had a statistical effect on mammography screening. Another study conducted in Malaysia, education, employment status, income, insurance and smoking were found to be significantly associated with the use of preventive medical care such as mammography (Cheah and Tang 2017). Aslaner (2019). On the other hand, this study revealed that while working status had a significant effect on mammography behaviors; marital status, educational status and income level did not make a difference in behaviors. Unlike the findings of Cheah and Tang (2017) and Aslaner (2019), Secginli and Nahcivan (2006) observed that employment status was not statistically significantly associated with the use of breast cancer screening.

Lack of education and lack of knowledge about mammography were found to have a significant adverse affect on the use of mammography among low-income women (Davis et al. 1996). In another recent study, it is determined that geographical inequalities and low socioeconomic status reduced the likelihood of early diagnosis in women (Shen, Chen and Hsieh 2020). Davis et al. (1996) determined that cost was one of the reasons for the decrease in the rate of mammography screening among low-income women.

What effect marital status has on breast cancer screening is a question of interest. Ghanbari et al. (2020) found that the breast cancer screening rate was low in married women. The same study determined that the social determinants 
had an important role in breast cancer screening (Ghanbari et al. 2020). Mammography performance was associated with the health insurance and the family history. Moreover, clinical breast examination was associated with the age of women, and the breast self-examination was associated with the age and profession of women (Ghanbari et al. 2020). In another study, alcohol consumption was examined and it was found to be not associated with the breast cancer screening (Matsubara et al. 2013).

Unlike the studies in the literature examining the relationship between income and breast cancer screening rates, the number of studies on income groups is quite limited. Gathirua-Mwangi et al. (2018) conducted one of the pioneering studies examining the mammography screening rates for different income groups. Their studies reported that there were differences in predictors of mammography compliance for different income groups. Age was found to be an important determinant in both low-income and high-income groups. Doctor's recommendation was significant only in the low income group (Gathirua-Mwangi et al. 2018).

\section{METHODS}

\subsection{Data}

The data used in this study, in which the mammography behaviors of women were examined, was obtained from Turkey Health Survey micro-data set conducted by the TURKSTAT in 2016. Since women over the age of 40 are recommended to have mammograms, women aged 40 and over were included in the study. In total, the whole sample consists of 5266 women.

Explanations and descriptive statistics for the variables are presented in Table 1. Table 1 suggests that more than half of the women (55\%) studied within the scope of the study had never had a mammogram in their lifetime. A very small portion of the women (19\%) worked, whereas the vast majority $(97 \%)$ were married (Table 1$)$.

Table 1. The Variables Included in the Analysis

\begin{tabular}{|c|c|c|c|}
\hline Variable Name & Explanations & $\mathbf{N}$ & Proportion \\
\hline Mammography & $\begin{array}{l}\text { When was the last time you had a mammogram/film mammography? } \\
\text { Never } \\
\text { Over } 5 \text { years ago } \\
\text { More than } 3 \text { years but less than } 4 \text { years } \\
\text { More than } 2 \text { years but less than } 3 \text { years } \\
\text { More than } 1 \text { year but less than } 2 \text { years } \\
\text { In the last } 12 \text { months }\end{array}$ & $\begin{array}{l}2894 \\
443 \\
314 \\
295 \\
552 \\
768\end{array}$ & $\begin{array}{l}54.96 \% \\
8.41 \% \\
5.96 \% \\
5.60 \% \\
10.48 \% \\
14.58 \%\end{array}$ \\
\hline Age & $\begin{array}{l}\text { Person's age } \\
\qquad \begin{array}{l}40-50 \\
51-60 \\
61-70 \\
70 \text { and over }\end{array}\end{array}$ & $\begin{array}{l}1918 \\
1475 \\
1057 \\
816\end{array}$ & $\begin{array}{l}36.42 \% \\
28.01 \% \\
20.07 \% \\
15.50 \%\end{array}$ \\
\hline Employment status & $\begin{array}{l}\text { Employment status in the last week } \\
\text { Working } \\
\text { Not working }\end{array}$ & $\begin{array}{l}988 \\
4278\end{array}$ & $\begin{array}{l}18.76 \% \\
81.24 \%\end{array}$ \\
\hline Marital status & $\begin{array}{l}\text { Marital status } \\
\qquad \begin{array}{l}\text { Never married } \\
\text { Married, divorced, spouse died }\end{array}\end{array}$ & $\begin{array}{l}143 \\
5123\end{array}$ & $\begin{array}{l}2.72 \% \\
97.28 \%\end{array}$ \\
\hline Income (TL) & $\begin{array}{l}\text { Average monthly income of the household } \\
\qquad \begin{array}{l}0-1264 \\
1265-1814 \\
1815-2540 \\
2541-3721 \\
3722 \text { and above }\end{array}\end{array}$ & $\begin{array}{l}1428 \\
1378 \\
912 \\
798 \\
750\end{array}$ & $\begin{array}{l}27.12 \% \\
26.17 \% \\
17.32 \% \\
15.15 \% \\
14.24 \%\end{array}$ \\
\hline Disease state & $\begin{array}{c}\text { Having an illness or not } \\
\text { Yes } \\
\text { No }\end{array}$ & $\begin{array}{l}3910 \\
1356\end{array}$ & $\begin{array}{l}74.25 \% \\
25.75 \%\end{array}$ \\
\hline
\end{tabular}


This study examined the mammography behaviors of women in Turkey and the last date to undergo a mammography screening was considered as the dependent variable. Considering the values of this variable (Table 1), it has an ordered structure. If the dependent variable has an ordered structure, different estimation methods can be used. In the following section, the Generalized Ordered Logit Model is explained and the estimation results obtained with this model are given.

\subsection{The Generalized Ordered Logit Model}

Methods such as the Ordinary Least Squares Regression requires dependent variables to be on a range or a ratio scale. When the dependent variable is ordered, different estimation methods should be used. The most popular method used in the literature is the ordered logit model, also known as the proportional probability model (Williams 2016: 7). The basic assumption of ordered logit models is the parallel regression assumption. The parallel regression assumption known as the proportional odds assumption of the ordered logit model is important in order to see the applicability of these models. However, in practice, this assumption is mostly not met. If this assumption is not met, the ordered logit model results cannot be trusted and alternative models should be used. If the Multinomial Logit Model is used as an alternative model, there would be a loss of efficiency in the estimation results since the modeling is created in an unordered structure despite the ordered structure of the dependent variable. One of the less constrained alternative models that do not require parallel regression assumption among ordered logit models is the Generalized Ordered Logit Model. This model takes into account the ordered structure of the dependent variable and does not restrict the proportional odds assumption. The Generalized Order Logit Model includes linear constraints, alternative model parameterization, automatic model fitting, options for alternative connection functions, and the calculation of the estimated probabilities via the estimation command (Williams 2006: 58).

For the ordered dependent variable with M category, the Generalized Ordered Logit model can be written as follows (Williams 2006: 59; Abrudan, Pop and Lazăr 2020: 11):

$$
P\left(Y_{i}>j\right)=g\left(X \beta_{j}\right)=\frac{\exp \left(\alpha_{j}+X_{j} \beta_{j}\right)}{1+\left\{\exp \left(\alpha_{j}+X_{j} \beta_{j}\right)\right\}} \quad, j=1,2, \ldots, M-1
$$

Here $M$ is the category number of the ordered dependent variable. In accordance with the equation numbered (1), each probability values for $Y$ from 1 to $M$ is calculated as follows:

$$
\begin{aligned}
& P\left(Y_{i}=1\right)=1-g\left(X_{i} \beta_{1}\right) \\
& P\left(Y_{i}=j\right)=g\left(X_{i} \beta_{j-1}\right)-g\left(X_{i} \beta_{j}\right) \quad j=2, \ldots, M-1 \\
& P\left(Y_{i}=M\right)=g\left(X_{i} \beta_{M-1}\right)
\end{aligned}
$$

When the category number of the dependent variable is $2(M=2)$, the generalized ordered logit model is equal to the logistic regression model. When $M>2$, the Generalized Ordered Logit Model equates to a set of binary logit models in which the categories of the dependent variable are combined. For example; assuming that the dependent variable consists of 4 categories, for $M=1$ category 1 is compared with the others. For $M=2$ categories 3 and 4 are compared against categories 1 and 2 . For $M=3$ categories 1,2 , and 3 are compared with category 4 . In this case, while the $\beta$ coefficients are estimated the same for some values of $\mathrm{j}$ in the Generalized Ordered Logit Model, they can be estimated differently for others (Williams 2006: 59). In other words, it generates much more parameters in the Generalized Ordered Logit Model compared to the Ordered Logit Model. Thus, it provides an opportunity to examine and interpret the effects of the explanatory variables on the categories of the dependent variable in more detail.

In this study, when the structure of the dependent variable (last mammogram date) is considered, the Ordered Logit Model was applied first. In order to control for the parallel slopes assumption of the Ordered Logit Model, the necessary tests were carried out and the results obtained are given in Table 2. As the parallel slopes assumption 
was not met, the Generalized Ordered Logit Model estimation results were obtained as an alternative method and these results are given in Table 3.

Table 2. Results of Testing the Parallel Slopes Assumption

\begin{tabular}{lcc}
\hline Tests & Chi2 & P>Chi2 \\
\hline Wolfe Gould & 121.8 & 0.000 \\
Brant & 118.8 & 0.000 \\
Score & 124 & 0.000 \\
Likelihood Ratio & 119 & 0.000 \\
Wald & 123.9 & 0.000 \\
\hline
\end{tabular}

Table 3. The Results of the Generalized Ordered Logit Model Regression

\begin{tabular}{|c|c|c|c|c|c|c|c|c|c|c|}
\hline \multirow[t]{3}{*}{$\begin{array}{l}\text { Last mam- } \\
\text { mogram } \\
\text { date }\end{array}$} & \multicolumn{10}{|c|}{$\begin{array}{l}\text { 1: Never, 2: More than } 5 \text { years ago, 3: More than } 3 \text { years but less than } 4 \text { years, } 4 \text { : More than } 2 \text { years but less than } 3 \text { years, } 5 \text { : } \\
\text { More than } 1 \text { year but less than } 2 \text { years, } 6 \text { : Within the last } 12 \text { months }\end{array}$} \\
\hline & \multirow{3}{*}{$\begin{array}{l}\mathrm{N}=5266 \\
\text { Never }\end{array}$} & \multicolumn{3}{|c|}{ Log Likelihood=-7049.3363 } & \multirow{2}{*}{\multicolumn{2}{|c|}{$\begin{array}{l}\text { LR chi2 }(50)=477.81 \\
\text { More than } 3 \text { years but } \\
\text { less than } 4 \text { years }\end{array}$}} & \multicolumn{3}{|c|}{ Prob $>$ chi $2=0.0000$} & \\
\hline & & & \multicolumn{2}{|c|}{$\begin{array}{l}\text { More than } 5 \text { years } \\
\text { ago }\end{array}$} & & & \multicolumn{2}{|c|}{$\begin{array}{l}\text { More than } 2 \text { years } \\
\text { but less than } 3 \\
\text { years }\end{array}$} & \multicolumn{2}{|c|}{$\begin{array}{l}\text { More than } 1 \text { year but less } \\
\text { than } 2 \text { years }\end{array}$} \\
\hline Variables & & $\begin{array}{l}\text { Odds } \\
\text { Ratio }\end{array}$ & & $\begin{array}{l}\text { Odds } \\
\text { Ratio }\end{array}$ & & $\begin{array}{l}\text { Odds } \\
\text { Ratio }\end{array}$ & & $\begin{array}{l}\text { Odds } \\
\text { Ratio }\end{array}$ & & $\begin{array}{l}\text { Odds } \\
\text { Ratio }\end{array}$ \\
\hline Age $40-50$ & $\begin{array}{l}0.469 * * * \\
(0.097)\end{array}$ & 1.598 & $\begin{array}{l}0.784 * * * \\
(0.106)\end{array}$ & 2.191 & $\begin{array}{l}0.920 * * * \\
(0.116)\end{array}$ & 2.510 & $\begin{array}{l}1.046 * * * \\
(0.129)\end{array}$ & 2.848 & $\begin{array}{l}1.178 * * * \\
(0.174)\end{array}$ & 3.247 \\
\hline Age $51-60$ & $\begin{array}{l}0.943 * * * \\
(0.096)\end{array}$ & 2.568 & $\begin{array}{l}1.173 * * * \\
(0.105)\end{array}$ & 3.232 & $\begin{array}{l}1.179 * * * \\
(0.115)\end{array}$ & 3.251 & $\begin{array}{l}1.244 * * * \\
(0.128)\end{array}$ & 3.471 & $\begin{array}{l}1.359 * * * \\
(0.172)\end{array}$ & 3.892 \\
\hline Age $61-70$ & $\begin{array}{l}0.637 * * * \\
(0.100)\end{array}$ & 1.890 & $\begin{array}{l}0.650 * * * \\
(0.110)\end{array}$ & 1.916 & $\begin{array}{l}0.714 * * * \\
(0.121)\end{array}$ & 2.042 & $\begin{array}{l}0.826 * * * \\
(0.134)\end{array}$ & 2.285 & $\begin{array}{l}0.960 * * * \\
(0.181)\end{array}$ & 2.613 \\
\hline Working & $\begin{array}{l}-0.140^{*} \\
(0.076)\end{array}$ & 0.869 & $\begin{array}{l}-0.106 \\
(0.078)\end{array}$ & 0.899 & $\begin{array}{l}-0.068 \\
(0.080)\end{array}$ & 0.934 & $\begin{array}{l}-0.058 \\
(0.085)\end{array}$ & 0.944 & $\begin{array}{l}-0.059 \\
(0.102)\end{array}$ & 0.943 \\
\hline $\begin{array}{l}\text { Married, } \\
\text { divorced, } \\
\text { spouse died }\end{array}$ & $\begin{array}{l}0.106 \\
(0.178)\end{array}$ & 1.112 & $\begin{array}{l}0.133 \\
(0.184)\end{array}$ & 1.142 & $\begin{array}{l}0.233 \\
(0.196)\end{array}$ & 1.262 & $\begin{array}{l}0.383 \\
(0.219)\end{array}$ & 1.467 & $\begin{array}{l}0.561 * \\
(0.295)\end{array}$ & 1.753 \\
\hline $\begin{array}{l}\text { Income } \\
1265-1814\end{array}$ & $\begin{array}{l}0.444 * * * \\
(0.080)\end{array}$ & 1.559 & $\begin{array}{l}0.321 * * * \\
(0.084)\end{array}$ & 1.378 & $\begin{array}{l}0.310 * * * \\
(0.089)\end{array}$ & 1.363 & $\begin{array}{l}0.237 * * \\
(0.095)\end{array}$ & 1.268 & $\begin{array}{l}0.192 \\
(0.121)\end{array}$ & 1.212 \\
\hline $\begin{array}{l}\text { Income } \\
1815-2540\end{array}$ & $\begin{array}{l}0.588 * * * \\
(0.089)\end{array}$ & 1.800 & $\begin{array}{l}0.498 * * * \\
(0.092)\end{array}$ & 1.645 & $\begin{array}{l}0.448 * * * \\
(0.097)\end{array}$ & 1.566 & $\begin{array}{l}0.320 * * * \\
(0.105)\end{array}$ & 1.377 & $\begin{array}{l}0.323 * * \\
(0.131)\end{array}$ & 1.381 \\
\hline $\begin{array}{l}\text { Income } \\
2541-3721\end{array}$ & $\begin{array}{l}0.803 * * * \\
(0.094)\end{array}$ & 2.231 & $\begin{array}{l}0.675 * * * \\
(0.096)\end{array}$ & 1.964 & $\begin{array}{l}0.639 * * * \\
(0.100)\end{array}$ & 1.895 & $\begin{array}{l}0.562 * * * \\
(0.106)\end{array}$ & 1.753 & $\begin{array}{l}0.693 * * * \\
(0.128)\end{array}$ & 2.000 \\
\hline $\begin{array}{l}\text { Income } \\
3722+\end{array}$ & $\begin{array}{l}1.066 * * * \\
(0.096)\end{array}$ & 2.904 & $\begin{array}{l}1.015 * * * \\
(0.097)\end{array}$ & 2.761 & $\begin{array}{l}0.965 * * * \\
(0.100)\end{array}$ & 2.624 & $\begin{array}{l}0.084 * * * \\
(0.085)\end{array}$ & 2.316 & $\begin{array}{l}0.788 * * * \\
(0.129)\end{array}$ & 2.198 \\
\hline $\begin{array}{l}\text { Present Ill- } \\
\text { ness }\end{array}$ & $\begin{array}{l}0.482 * * * \\
(0.068)\end{array}$ & 1.619 & $\begin{array}{l}0.471 * * * \\
(0.070)\end{array}$ & 1.602 & $\begin{array}{l}0.449 * * * \\
(0.073)\end{array}$ & 1.567 & $\begin{array}{l}0.432 * * * \\
(0.078)\end{array}$ & 1.540 & $\begin{array}{l}0.530 * * * \\
(0.100)\end{array}$ & 1.699 \\
\hline Constant & $\begin{array}{l}-1.703 * * * \\
(0.203)\end{array}$ & 0.182 & $\begin{array}{l}-2.212 * * * \\
(0.213)\end{array}$ & 0.110 & $\begin{array}{l}-2.624 * * * \\
(0.228)\end{array}$ & 0.073 & $\begin{array}{l}-3.068 * * * \\
(0.255)\end{array}$ & 0.047 & $\begin{array}{l}-4.138 * * * \\
(0.349)\end{array}$ & 0.016 \\
\hline
\end{tabular}

Notes: (i) values in parentheses are standard errors. (ii) ***, ** and * indicate the $1 \%, 5 \%$ and $10 \%$ significance levels, respectively. (iii) $\mathrm{N}$ is the number of sample units, shows the coefficients.

Using the data of Turkey Health Survey, the factors affecting the mammography screening time of women were estimated with the Generalized Ordered Logit Model and the results are given in Table 3. From Table 3, one can clearly see that the effect of the age and disease status of women on mammography behaviors is statistically significant. At the same time, it is determined that there is a statistically significant difference in the frequency of mammography screening, depending on the differences observed in income levels. On the other hand, the marital status and the employment status of a woman are found to affect the mammography behavior only in some categories. 
Women between the ages of 40-50 are 3.25 times more likely to have a mammogram in more than 1 year but less than 2 years compared to the probability of having a mammogram in the last 12 months, compared to those over 70. The same probability is 3.90 times higher in women between the ages of 51-60, and 2.61 times higher between the ages of 61-70. Compared to those over the age of 70, the probability of never having a mammogram is approximately 1.60 times higher for women among the ages of 40 and 50. While it is 2.60 times higher in women aged 51-60 years, it is 1.89 times higher among the ages of 61-70. Moreover, our results suggest that women between the ages of 51-60 are more likely to have mammograms compared to other age groups.

The model results suggest that the probability of not having mammograms at all is reduced if among working women. In other words, if a woman works, her possibility of having a mammogram increases. Furthermore, married women are 1.75 times more likely to have a mammogram in more than 1 year but less than 2 years compared to the base category. We also found that the probability of women undergoing mammography increases in case of any diseases.

It is seen that the frequency of mammography increases with the increase in income level. For example, women in the highest income level are found to be approximately 2.2 times more likely to have a mammogram in more than 1 year but less than 2 years compared to women in the lowest income level.

\section{CONCLUSION}

This study focused on determining the demographic factors affecting the mammography behaviors of women over the age of 40. The data obtained from Turkey Health Survey 2016 questionnaire conducted by TURKSTAT were estimated with the generalized ordered logit model.

Our findings suggest that there was a difference in mammography behaviors depending on age and income. Healthcare providers should be aware of these differences observed in income and age and highlight strategies that increase mammography compliance for each income group.

Although marital status was not found to be a significantly effective factor, as far as is known from the literature, the breast cancer screening rate is low among married women. At this point, taking the cultural barriers into account, effective health education programs should be conducted and new ones should be implemented in order to increase the effectiveness of screening programs.

Lack of education and misconceptions are the main obstacles to cancer screening, so effective community-based health education is necessary to take structural and cultural barriers into account, reduce inequality in health care and increase the effectiveness of screening programs. Healthcare providers should take the time to educate women on mammography and help low-income women in particular determine how much screening costs. Providing efficient and timely screening services might increase the likelihood of receiving screening services.

Although this study fills an important gap in terms of examining mammography behaviors in different income and age groups in Turkey, it is very open to development. For example, family history should be taken into consideration, along with geographical inequalities and socioeconomic determinants. At the same time, breast cancer screening programs should be revised when necessary by observing the effect of training and health services provided with the help of longitudinal studies.

\section{Funding}

The author declares that this study has no financial support. 


\section{REFERENCES}

- ABRUDAN, I. N., POP, C. M., LAZĂR, P. S. (2020). Using a General Ordered Logit Model to Explain the Influence of Hotel Facilities, General and Sustainability-Related, on Customer Ratings. Sustainability, 12(21), 9302.

• AKOVA, İ., HASDEMIR, Ö., TÜRKOĞLU, H. (2019). Bir İlde 40-69 Yaş Kadınlarda Meme Kanseri Taramalarının Değerlendirilmesi. Bozok Tip Dergisi, 9(1), 89-92.

- ASLANER, Ç. (2019) Bir Aile Sağlığı Merkezine Başvuran Kadınların Meme Kanserinden Korunma Davranışlarının Karma Yöntemlerle Araştırılması, Uzmanlık Tezi, İstanbul Üniversitesi, İstanbul Tıp Fakültesi, İstanbul.

- AŞKIN, M., KOÇ, E. M., ARSLAN, M., ATEŞ, M. Y., DAĞ, G., SÖZMEN, M. K. (2019). Kadınların Meme Kanseri Taramalarına Katılımlarını Etkileyen Demografik Değişkenler. İzmir Eğitim ve Araştırma Hastanesi Tip Dergisi, 23(1), 25-32.

- BHANDARI, D., SHIBANUMA, A., KIRIYA, J., HIRACHAN, S., ONG K. I. C., JIMBA, M. (2021). Factors Associated With Breast Cancer Screening Intention in Kathmandu Valley, Nepal. PLoS ONE 16(1), 1:15.

- CHEAH, Y. K., TANG, C. F. (2017). Factors Influencing The Use Of Preventive Medical Care in Malaysia: Evidence From National Health And Morbidity Survey Data. Asian Economic Journal, 31(2), 119-137.

- DAVIS, T. C., ARNOLD, C., BERKEL, H. J., NANDY, I., JACKSON, R. H., GLASS, J. (1996). Knowledge And Attitude On Screening Mammography Among Low-Literate, Low-Income Women. Cancer: Interdisciplinary International Journal of the American Cancer Society, 78(9), 1912-1920.

- GATHIRUA-MWANGI, W., COHEE, A., TARVER, W. L., MARLEY, A., BIEDERMAN, E., STUMP, T., RAWL, S. SKINNER, C.S. CHAMPION, V. L. (2018). Factors Associated With Adherence To Mammography Screening Among Insured Women Differ By Income Levels. Women's Health Issues, 28(5), 462-469.

- GHANBARI A., RAHMATPOUR P., HOSSEINI N., KHALILI M. (2020). Social Determinants of Breast Cancer Screening Among Married Women: A Cross-Sectional Study. J Res Health Sci. 20(1).

- GLOBOCAN. (2020) https://gco.iarc.fr/today/data/factsheets/populations/900-world-fact-sheets.pdf, [Data Accessed: $10 / 5 / 2021]$

- HEALTH STATISTICS YEARBOOK, The Ministry of Health of Turkey. (2019) https://dosyasb.saglik.gov.tr/ Eklenti/40566, health-statistics-yearbook-2019pdf.pdf?0, [Data Accessed: 9/5/2021]

- KARACA, M., BİlgeteKİN, İ., AVŞAR, E., ÖZTÜRK, B. (2019). Meme Kanserinin Erken Tanısında Klinik Bulgular mi? Mamografi mi?. Akd Tip D. 5(3):510-5.

- MATSUBARA, H., HAYASHI, K., SOBUE, T., MIZUNUMA, H., SUZUKI, S. (2013). Association Between Cancer Screening Behavior And Family History Among Japanese Women. Preventive Medicine, 56, 293-298.

- NATIONAL CANCER INSTITUTE. (2015). Breast Cancer Screening Programs in 26 ICSN Countries, 2012: Organization, Policies, and Program Reach.

- SECGINLİ, S., NAHCIVAN, N. O. (2006). Factors Associated With Breast Cancer Screening Behaviours in A Sample Of Turkish Women: A Questionnaire Survey. International Journal of Nursing Studies, 43, 161-171.

- SHEN, C. T., CHEN, F. M., HSIEH, H. M. (2020). Effect Of A National Population-Based Breast Cancer Screening Policy On Participation in Mammography And Stage At Breast Cancer Diagnosis in Taiwan. Health Policy, 124(4), 478-485.

- TORRE, L. A., BRAY, F., SIEGEL, R. L., FERLAY, J., LORTET-TIEULENT, J., JEMAL, A. (2015). Global cancer statistics, 2012. CA: A Cancer Journal For Clinicians. 65(2), 87-108. 
- WILLIAMS, R. (2006). Generalized ordered logit/partial proportional odds models for ordinal dependent variables. The Stata Journal, 6(1), 58-82.

- WILLIAMS, R. (2016). Understanding and interpreting generalized ordered logit models. The Journal of Mathematical Sociology, 40(1), 7-20. 